\title{
Divulgando a evolução biológica para o grande público
} Educating the general public about biological evolution

\author{
Verlan Valle Gaspar Neto \\ Doutorando de antropologia pela Universidade Federal Fluminense \\ verlan02@yahoo.com.br
}

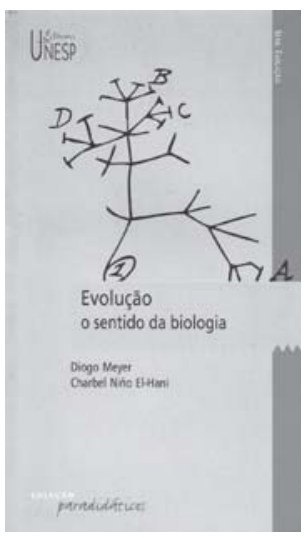

Meyer, Diogo; El-Hani, Charbel Niño. Evolução: o sentido da biologia. São Paulo: Editora da UNESP, 2005. 132p.
$\mathrm{H}$ á quase um século e meio, Darwin e Wallace alarmaram o mundo ocidental com suas proposições sobre a origem e a diversidade dos seres em nosso planeta, desafiando a concepção de que nós, seres humanos, possuímos uma posição inigualável no reino natural. De lá para cá, ao que parece, permanece a sensação de ofensa que muitas pessoas experimentam quando confrontadas com a máxima biológica de que os macacos são nossos parentes próximos. Afinal, quase ninguém gosta de refletir sobre a sua condição de primata sem cauda. Alguém poderia refutar que a razão para essa atitude se respalda em certas convicções religiosas - o que pode até ser verdade - ou que a simples proximidade entre um ser humano e um chimpanzé macula a árvore genealógica de qualquer família com nome e sobrenome - uma boa perspectiva, mas não esgota a questão.

Esse tipo de postura apresenta ao menos duas razões. A primeira delas é a pura e simples antipatia que muitas pessoas, tal como eu, nutrem pelos macacos. A segunda apresenta uma característica paradoxal: ela nega o parentesco símio não porque dele descrê, mas pelo justo fato de residir, em seu foro íntimo, a vaga noção de que nós, humanos, somos descendentes dos macacos. Como isso é possível? Basta observar as propagandas envolvendo evolução e você não precisará se esforçar para entender por quê.

Essa é, possivelmente, uma realidade que se espraia por todos os cantos, da feira popular aos bancos universitários, mostrando o quão desfamiliarizadas são as pessoas no que concerne à evolução biológica, quase sempre associada apenas à pretensa ancestralidade dos macacos sobre os humanos. Pode até parecer hilário que em tempos pós-modernos, numa população moldada nos ditames do desenvolvimento político, econômico e científico ocidentais, essa não seja ainda uma questão sanada.

A despeito de qualquer incongruência que possa haver entre a perspectiva evolucionista da biologia e alguns preceitos religiosos, o que se tem, em boa medida, é a ausência de informação científica, principalmente de modo claro, leve e objetivo. E é nesse ponto que saúdo Evolução: o sentido da biologia, em que é possível notar o esforço dos autores em mostrar que não somos filhos de macacos e, indo mais além, ao demonstrar que a diversidade de vida que se nos apresenta cotidianamente possui um mecanismo possibilitador: a evolução. 
Em linhas gerais, o objetivo da obra é tratar a evolução em biologia sob uma perspectiva bem abrangente e acessível, aproximando o tema do cotidiano de estudantes do ensino médio e do público leigo em geral. Nela são apresentados tanto as bases do evolucionismo quanto os debates atuais, levando-se em conta a história e a filosofia das ciências, de modo a contextualizar o tema da evolução em termos históricos, culturais e filosóficos. Partindo de exemplos que envolvem a existência de penas nas aves, o canibalismo entre aranhas australianas e a epidemia de HIV, entre outros, os autores pretendem chamar a atenção do leitor para a importância do estudo da evolução. É que apenas descrições de estruturas e análises factuais não são capazes de explicar tais fenômenos. Características e comportamentos no universo natural podem ser explicados (ou interrogados) por meio da evolução, que funciona como uma espécie de pedra de roseta da biologia.

O livro, dividido em cinco capítulos, cumpre bem a proposta de informar sem ser demasiado tecnicista. Os autores apresentam proposições para lá de interessantes sobre o papel da evolução no desenvolvimento da vida e do próprio conhecimento científico a partir do evolucionismo. Desse modo, o leitor pode constatar que a evolução de fato existe e que ocorre bem debaixo de nossos narizes. E o que seria a evolução? Ora, em termos bastante simples, é a ocorrência de descendência com modificação, ou seja, a transformação dos organismos ao longo do tempo. Esse é o mote central do primeiro capítulo do livro de Meyer e El-Hani, no qual eles apresentam a evolução como princípio gerador de diversidade na natureza, convidando-nos a reconhecer que ela aproxima os seres por meio de laços de parentesco a partir de ancestrais comuns. E mais, que os fenômenos observados envolvendo a vasta variedade de espécies que conhecemos só são passíveis de ser entendidos sob uma perspectiva que reconhece o dinamismo como um atributo intrínseco à natureza.

Assim, não fica difícil para o leitor entender por que o capítulo 2 insiste na ideia de que a mudança é a regra na natureza, e não a exceção. Nele são apresentadas as correntes teóricas que se debruçaram sobre o tema da diversidade de espécies, partindo do fixismo que vigorou até meados do século XIX até chegar à obra-prima de Charles Darwin, $A$ origem das espécies, lançada em 1859 e que revolucionou o modo ocidental de encarar a natureza. Por aqui passeiam os pressupostos fixistas, que previam a imutabilidade dos seres e a existência de um Deus criador que fez o mundo tal como o conhecemos hoje, bem como as proposições dos precursores do evolucionismo nos séculos XVIII e XIX, Buffon e Lamarck, respectivamente, além do darwinismo resultante dos trabalhos desenvolvidos por Darwin e Wallace. Ao mesmo tempo, são apontadas algumas evidências da real existência da evolução. Para tanto, os autores recorrem a exemplos envolvendo os registros fósseis, as semelhanças estruturais entre algumas espécies, os órgãos vestigiais em alguns animais, entre outros. No mesmo capítulo são apresentados também os pontos centrais sobre os quais se edifica o darwinismo, cujo destaque recai, obviamente, sobre a seleção natural, tema aprofundado no capítulo posterior.

Um aspecto interessante do capítulo 2 é como os autores conjugam encadeamentos históricos do desenvolvimento do evolucionismo, exemplos cotidianos, e discussões um pouco mais profundas, para discorrer sobre a seleção natural. Nele, é possível ver como, depois de um breve período de obscurantismo e críticas, a ideia de evolução com base na seleção natural foi retomada em conjunto com o legado experimental de Mendell ainda 
no princípio do século $\mathrm{XX}$, dando origem ao que se convencionou chamar de teoria sintética da evolução. E para mostrar a força desse mecanismo de triagem, cerne da biologia evolutiva, Meyer e El-Hani recorrem às superbactérias resistentes a antibióticos, peixes que mudam de tamanho e machos de aranhas que se entregam ao canibalismo de suas parceiras reprodutivas, de modo a obter o maior número de descendentes possível. Em todos esses casos, está em jogo o poder atuante da seleção natural. Ao mesmo tempo, são indicados outros fatores que, associados ou não a esse mecanismo, também agem sobre a evolução dos seres.

Se a seleção natural não explica tudo, mas explica muita coisa - e isso é certo - é importante então que o leitor se familiarize com uma característica relevante do métier científico. Isso porque as proposições científicas não são verdades dogmáticas, mas sim proposições passíveis de crítica e refutação. O capítulo quarto de Evolução trata justamente dos debates atuais na biologia evolutiva, apontando o que o paleontólogo Stephen Jay Gould considera os três desafios do neodarwinismo: a identificação do nível de atuação da seleção natural (agência), o poder explicativo desse mecanismo (alcance) e a sua eficiência (eficácia). Agência, alcance e eficácia são três dimensões do pensamento evolutivo envolvendo a seleção natural que merecem atenção cuidadosa por causa da miríade de perspectivas que os estudos e experimentos vêm demonstrando nessa área. Muita coisa mudou desde a publicação de $A$ origem das espécies, há um século e meio, e embora Darwin tenha apresentado respostas ainda válidas para as perguntas que os biólogos continuam se fazendo até hoje, os horizontes atualmente são muito mais amplos.

Mesmo se nos restringirmos apenas a uma das questões debatidas no livro, referente ao que é selecionado (agência), é possível ver as transformações pelas quais a biologia evolutiva passou desde meados do século XIX. Para Darwin, a seleção natural agiria sobre organismos individuais, e os comportamentos altruístas eram um desafio à sua teoria, já que ele dera demasiada ênfase à competição entre os seres. Mais tarde, novas perspectivas foram incorporadas. Na década de 1960, Vero Wynne-Edwards, postulou que a seleção agiria sobre grupos e, com o passar do tempo, grupos altruístas prevaleceriam, enquanto os egoístas tenderiam a desaparecer. George C. Williams criticou tal perspectiva, apresentando a versão da 'subversão desde dentro', na qual indivíduos altruístas pereceriam na competição com indivíduos egoístas. Sendo dessa forma, bastaria apenas um egoísta dentro de uma população altruísta para que, com o passar do tempo, o grupo fosse amplamente dominado pelos egoístas. Mas a questão da existência do altruísmo não estava respondida. Foi quando William Hamilton propôs que a atuação de um indivíduo altruísta favorece, na verdade, a sobrevivência de seus parentes próximos e, consequentemente, de seus genes; esse mecanismo ficou conhecido como seleção desde dentro. Como se pode ver, todas essas respostas divergem daquela oferecida por Darwin para o escopo de atuação da seleção natural. Se para o pai do darwinismo a seleção natural atuaria apenas sobre organismos individuais, para Wynne-Edwards e Williams ela agiria sobre populações, enquanto Hamilton desloca essa atuação para os genes.

Esse é apenas um dos pontos explorados no capítulo 4, e a breve incursão feita aqui não corresponde ao detalhamento com que eles são apresentados no texto, evidenciando-se uma perspectiva epistemológica e histórica. Na mesma esteira, os tópicos referentes à eficácia 
e ao alcance da seleção natural levam em consideração as convergências e divergências, desde as respostas oferecidas por Darwin até os dias de hoje, o que compõe um mosaico bastante rico do desenvolvimento da biologia evolutiva no último século. Ajuntam-se a essa configuração questões emergentes com o advento dos estudos da biologia do desenvolvimento e as restrições ao processo evolutivo.

O quinto e último capítulo encerra o livro por meio de duas frentes. Na primeira, encontram-se mais alguns exemplos cotidianos; é a parte empírica corroborando a existência da evolução através da seleção natural. A outra nada mais é do que um diálogo com os argumentos criacionistas diante da diversidade dos seres e a existência de um processo evolutivo que a subjaz, assunto que será retomado adiante.

Para Meyer e El-Hani, a compreensão tanto da origem do HIV como das estratégias caras ao seu enfrentamento passam por questões evolutivas. Do mesmo modo, a resistência a antibióticos, por parte das bactérias, também pode ser compreendida invocando-se a seleção natural, posto que, nesse cenário, os medicamentos funcionam como agentes evolutivos. Esses são exemplos acertados de como se pode aproximar ciência e cotidiano de modo inteligente e esclarecedor. A epidemia de Aids e o uso indiscriminado de antibióticos são fenômenos tão próximos da existência das pessoas, que fica fácil para um estudante secundarista, ou mesmo para um leigo, entender, através deles, como funciona a evolução por meio da seleção natural. No caso específico do HIV, o mais interessante é que tanto a origem do vírus (o HIV-1 e o HIV-2 são originários do vírus da imunodeficiência símia, SIVs, encontrados em macacos) como as dificuldades enfrentadas no tratamento da doença possuem causas que podem ser explicadas evolutivamente. Isso propicia melhor compreensão desse que se tem mostrado um dos maiores flagelos pelos quais a humanidade já passou. Ainda assim, um terceiro exemplo mostra como a evolução pode explicar alguns tipos de comportamento, como o fato de as mulheres enjoarem muito nos primeiros meses de gestação. Segundo os autores, estudos de natureza médica, psicológica e antropológica revelaram que isso ocorre porque é nesse período que o embrião está mais suscetível a sofrer ameaças de má-formação e até mesmo aborto. O enjoo seria então um mecanismo através do qual as mulheres evitariam determinados alimentos em função de eles serem potencialmente tóxicos para o embrião.

Ao que tudo indica, nada do que é observado na natureza, referente à vida em toda a sua diversidade, pode ser explicado sem que se tenha uma perspectiva evolutiva em mente. Sabe-se dos problemas que esse tipo de raciocínio implica quando confrontado com os pressupostos de algumas religiões. Meyer e El-Hani procuraram responder a alguns dos questionamentos levantados pelos criacionistas quanto à real existência da evolução das espécies. Afinal de contas, não é simples para um fundamentalista, ou mesmo para um adepto religioso mais moderado, colocar um mecanismo autônomo no lugar de Deus no 'projeto' de criação. A preocupação que os autores demonstraram nesse livro é, efetivamente, pertinente, já que temos assistido nos últimos anos a uma retomada da cruzada criacionista contra as explicações científicas sobre a origem da vida e a diversidade das espécies - incluídos ecos no Brasil, onde em alguns momentos se cogitou a substituição da teoria da evolução pelos preceitos explicativos religiosos nas escolas públicas. Lembro apenas que o leitor não encontrará aqui um ataque direto ao criacionismo, mas antes uma defesa daquela que se 
tem mostrado ao longo de mais de um século uma explicação ao menos razoável e factível para a origem da diversidade de seres em nosso planeta.

Evolução: o sentido da biologia pode ser indicado para todo leitor curioso o suficiente para questionar a realidade natural que o cerca. Ao ler o livro, é possível que ele encontre as respostas para muitos de seus questionamentos. Mas é verdade também que nem tudo será respondido, o que é bom, porque isso lhe mostrará que, contrariamente ao dogmatismo religioso, a ciência não se pode valer de verdades a qualquer custo, e suas proposições são sempre passíveis de revisitação e refutação, para tanto se bastando de pesquisas e experimentos. E no que se refere ao estudo da biologia em si, este resenhista vê-se obrigado a concordar com os autores da obra por hora resenhada. Não há biologia sem evolução, porque é essa perspectiva que permite a todos os ramos das ciências biológicas dialogar de modo a compreender os fenômenos e os seres aos quais se lançam. Afinal, a vida não para de se reinventar. Além de que, ao ler esse livro, quem sabe muitas pessoas deixem de se sentir incomodadas pelo fato de ser parentes de um macaco. Antes primos do que netos. 